GRECHANA S. I.,

Judge

(Central District Court of Nikolaev)

UDC 342.951:347.793

DOI https://doi.org/10.32842/2078-3736/2020.3.19

\title{
FEATURES OF THE FORMATION AND DEVELOPMENT OF ADMINISTRATIVE PROCEEDINGS
}

The article is devoted to the study of the features of the development of administrative justice - a system of special bodies (courts) for monitoring compliance with the law in the field of public administration, namely, a special procedural procedure for resolving administrative-legal disputes between citizens, public organizations or institutions, on the one hand, and government bodies, their officials, on the other hand, belong to pre-revolutionary times [1].

Studies of the institute of administrative legal proceedings in Ukraine at different historical stages of social development (from the existence of Kievan Rus to Ukraine's independence is relevant, since the stages of formation and development of administrative courts are inextricably linked with the stages of development of the Ukrainian state as a whole. Such periodization makes it possible to accurately trace reform of administrative courts and their modernization. It is determined that the formation and development of administrators court proceedings are inextricably linked with the stages of development of the Ukrainian state as a whole - starting with separate rules in customary law during the time of Kievan Rus, due to the emergence of administrative courts in the Austro-Hungarian and Russian empires, the formation and strengthening of Ukrainian statehood, the UPR, revolutions, etc..d. Administrative law was part of flax law, regulated relations between seniors and vassals, and had a private legal basis [2].

The emergence of the administrative court system itself is associated with the formation and development of administrative proceedings in the AustroHungarian and Russian empires, since for a long time the Ukrainian lands were under their authority. It was in those days that the question was raised of the administration of justice by professional judges who are in the service of the state [3].

Key words: justice, administrative legal proceedings, administrative-legal disputes, government bodies, legality, justice.

\section{Гречана С. І. Особливості становлення і розвитку адміністративного судочинства}

Стаття присвячена дослідженню особливостей розвитку адміністративної юстиції - системи спеціальних органів (судів) із контролю за дотриманням законності у сфері державного управління, а саме: особливого процесуального порядку вирішення адміністративно-правових спорів між громадянами, громадськими організаціями чи установами, з одного боку, і органами державного управління, їхніми посадовими особами, з іншого боку [1].

Дослідження інституту адміністративного судочинства в Україні на різних історичних етапах суспільного розвитку (від існування Київської Русі до здобуття Україною незалежності) є актуальним, оскільки етапи становлення і розвитку адміністративних судів нерозривно пов'язується з етапами розвитку української держави в цілому. Така періодизація надає змогу безпомилково

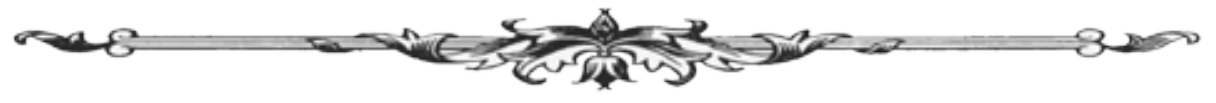


прослідкувати за реформуванням адміністративних судів та становленням їх у сучасному вигляді. Визначено, що становлення та розвиток адміністративного судочинства нерозривно пов'язанні $з$ етапами розвитку української держави в цілому - починаючи з окремих норм у звичаєвому праві d часи Київської Русі, через виникнення адміністративних судів в Австро-Угорській і Російській імперіях, період становлення і укріплення української державності, УНР, революцій і т.д. Адміністративне право було частиною ленного права, яке врегульовувало відносини між сеньйорами і васалами і мало приватноправову основу [2].

Виникнення самої системи адміністративних судів пов'язують із становленням і розвитком адміністративного судочинства в Австро-Угорській і Російській імперіях, оскільки тривалий час українські землі перебували під їх владою. Саме в ті часи ставилося питання про здійснення правосуддя професійними суддями, які перебувають на службі в державі [3].

Ключові слова: правосуддя, адміністративне судочинство, адміністративноправові спори, органи державного управління, законність, юстиція.

Introduction. Another Ukrainian Hetman Pylyp Orlyk, in his "Pacts and Constitution of laws and liberties Zaporizhia army" (1710) laid the idea of natural law and the contractual origin of state, according to which the people of Ukraine enters into a contract with a Hetman transferring him a part of their rights and liberties for the sake of securing internal consent and external safety of the state. The document formulated principles of division of representative and Executive power and independence of the court, which must obey only the law. Later the ideas of justice, liberty, equality and fraternity were mentioned in the documents of the Cyrillo-Methodian society (1845-1847). Steps to a harmonious society made great Ukrainians Mykhailo Drahomanov and Mykhailo Hrushevsky [3].

Statement of the problem. The purpose of this article is to study the historical aspects of the development of administrative procedure.

The results of the study. The development of the Institute of administrative justice has gained pre-revolutionary Russia, which had such characteristics as:

1. The imperfection of construction of the system of its bodies, which was manifested in the lack of a clear division of competences between them which, in turn, led to violations instance cases.

2. The lack of inherent proceedings of the principles of transparency, competitiveness in the activities of these bodies, as well as the underdevelopment of promoting forms of their activity that essentially turned these bodies of bodies of administrative justice in the bodies of administrative arbitrariness.

3. Participation in the proceedings of representatives of the active administration, i.e., ignoring the principle that you cannot be a judge in his own case, and also the unsatisfactory solution of the personnel question of the composition of these bodies from the point of view of professional competence and educational level [4].

The principle "not one to judge without the court" adhered to by the leaders of the Soviet government, after the victory of the October revolution, which made an attempt to form a national judicial system in 1918-1921. In the Constitution of the UNR 1918 was declared overall progressive principles of organization and activities of the national judiciary. The report on the activities of the Poltava Military Revolutionary Committee and its departments in 1919. stated the following: "currently the most urgent task of the legal Department is the establishment of the judicial system across the province" [10]. In Soviet times, the further development of the right of appeal in court of actions of officials zakrylas in the USSR Constitution 1977 and the Constitution of Ukrainian SSR 1978. Special act, which guaranteed this right was the Law of the USSR "On the procedure for appealing to a court unlawful actions of officials violating the rights of citizens". To realize these principles did not allow that in the 20-ies of XX century. in Ukraine, began to form the system of the Soviet judicial system, which functioned until the demise of the Soviet Union in 1991 [5].

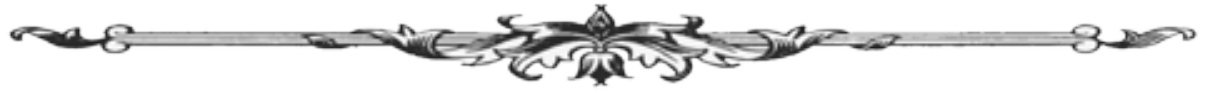


Indeed it was not judicial proceedings. However, since Soviet times, nothing substantial in this respect has not changed. Occurred only the replacement of some officials in other administrative and party bodies, and in certain cases, and public organizations. Moreover, there have been arguments in favor of consideration of administrative cases by the administrative authorities: 1) matters of administrative law must be in the conduct of most administrative authorities; 2) justice (the court) has no right to interfere in the Affairs of the administration; 3 ) judges of common courts is not prepared for the consideration and resolution of specific disputes within the scope of public law [6].

There were other approaches, but the question was raised about the creation of special courts to review administrative cases in the sphere of public law relations. In the end, during the Soviet period was introduced:

1) bringing to administrative responsibility is exercised by the administrative bodies;

2) consideration of citizens complaints - also by administrative bodies (in some cases, public organizations);

3) challenge of illegal actions of the authorities are also in the higher administrative authorities;

4) abolition of illegal acts of a higher order [3].

Public-legal disputes was considered by the rules of civil procedure. However, the introduction of administrative justice has only been formally, in practice the powers of the judges in the consideration of public law disputes was very limited. The system of administrative courts due to the presence of such factors as insufficient level of activity of bodies of state power, which adversely affects the rights and freedoms of citizens.

Considering the case in the procedure established by the Civil procedural code of Ukraine 1963., were not allowed the cancellation of illegal administrative acts was only possible, or to break the power of the administrative authority which has issued a disputed act, to repeal it or amend it or to appeal to a higher administrative authority with the requirement about cancellation of illegal act. It's caused some delays and provided no real face protection.

The judicial system of the USSR was guided by the Regulation "On the judicial system of the USSR on the territory of the Republic", approved by the Ukrainian Central Executive Committee, which introduced a unified judicial system headed by the Supreme Court of the Ukrainian SSR [7].

The USSR Constitution of 1977. reinforcing that actions of officials, committed in violation of the law, abuse of authority and violating the rights of citizens, may be in accordance with the law challenged in court. Citizens of the USSR have the right to compensation for damage caused by unlawful actions of state and public organizations, and also officials at execution of official duties. Similar provisions are enshrined in article 56 of the Constitution of Ukrainian SSR 1978.

In the Soviet constitutions, the principle of separation of powers has not found its proper continuation. They fixed the judicial system, but said nothing about the judiciary as a separate branch of government [8].

Of course, in independent Ukraine without change, there can be a court on the model of the Soviet time. The act of independence of Ukraine adopted by the Verkhovna Rada of Ukraine 24.08.1991 and approved by all-Ukrainian referendum, led to the carrying out of various reforms in the state. That is for the period 1992-1993 have the holding of the first democratic judicial reform, during which were adopted important laws of Ukraine on the judicial system, the Charter of judges, etc. But to fully implement this reform did not allow the lack of adequate constitutional provisions on justice.

The first step towards creating a system of administrative justice of Ukraine was the adoption in 1992 of the Concept of judicial reform. Since 1996, the working group headed by First Deputy Chairman of the Supreme Court of Ukraine. Stefanyka, began preparation of a draft Administrative procedure code. Scientific substantiation of this important document, provided such outstanding Ukrainian scientists and experts in their field as V.B. Averyanov, V.I. Andreytsov, Y.P. Bytyak, R.A. Kalyuzhny, V.K. Kolpakov, V.V. Kopeychykov, V.G. Perepelyuk and others. His research, through review of historical development the nature of administrative proceedings, the experts have created theoretical basis of the Institute of administrative justice in Ukraine as a new branch of the law [6].

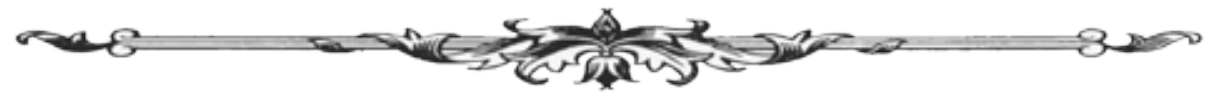


The idea of creating administrative courts in independent Ukraine, was published in 1992, the Concept of judicial reform, approved by the resolution of the Supreme Council of Ukraine "On the concept of judicial reform in Ukraine as of April 28, 1992 № 2296-XII with subsequent development of the Constitution of Ukraine. In particular, article 124 of the Constitution of Ukraine stipulates that the jurisdiction of courts covers all legal relations arising in the state and in article 125 of the Constitution provides for the establishment of specialized courts" [9].

However, the implementation of the Basic Law was an obstacle outdated legislation on the judicial system in Ukraine. The proclamation of the judicial reform in Ukraine and securing its priorities in the Law of Ukraine "On judicial system of Ukraine" of 07.02.2002, has created objective preconditions for increase of efficiency of functioning of courts of General jurisdiction. The necessity of its existence and ability to fairly resolve legal conflicts in society, and the state courts of General jurisdiction have argued repeatedly [10].

The development of administrative justice in Ukraine was provided gradually Concepts judicial reform: beginning with the specialization of judges and the establishment of specialized judicial boards and ending with the creation of the vertical of administrative courts [11].

After fixing the Constitution of Ukraine of 1996, the universal rules to appeal in court the decisions, actions or omission of bodies of state power, bodies of local self-government, their officials and officers and jurisdiction of courts to all legal relations arising in the state, the creation of the vertical of administrative courts became apparent. But first create a system of administrative courts took almost ten years [12].

The establishment of a system of administrative courts with the purpose of full judicial protection of the rights and freedoms of citizens in the sphere of public-legal relations is provided by the Concept of administrative reform in Ukraine approved by the President of Ukraine in 1998 [13].

At the legislative level for the first time this has been determined by the Law of Ukraine "On judicial system of Ukraine" from 2002 with changes. The law not only identified the place of administrative courts in the system of courts of General jurisdiction, but set a three-year period to create them. As a consequence, in part 2 of article 1 of this Law States that judicial power is realized through the implementation of justice in the form of civil, commercial, administrative, criminal, and constitutional proceedings [14].

Pursuant to the provisions of the Act of October 1, 2002, the President of Ukraine signed the Decree "On establishment of the Supreme administrative court of Ukraine".

The activities of the administrative courts is not aimed at punishing the wrongful conduct of the citizen, but rather the priorities of administrative justice lie in the protection of human rights, the restoration of the legitimate state. The main purpose of administrative justice is the restoration of violated rights. Such recovery can be done one way - the cancellation of illegal administrative act.

The important rule laid down in the Constitution all the rights and freedoms of man and citizen are protected by the courts, i.e. the jurisdiction of courts covers all legal relations arising in the state. A court decision citizens and other interested legal entities may defend their constitutional rights. In the case where the decision of domestic courts not satisfy the plaintiffs, they can appeal to the European judicial institutions. This rule is also derived from the Constitution of Ukraine [15].

Reforms and measures to improve justice and increase the status of judges are aimed at the implementation of constitutional norms, which should help to overcome many negative phenomena inherent in this system, in particular, the alienation between the individual and state and legal structures of different levels and levels. Reorganization of the justice system and its bodies can create preconditions for overcoming this alienation, turn the court into a real guarantor of individual freedom [16].

Our state has been trying for a long time to form a system of public administration that will be close to human needs, and the priority of its activities will be to serve the people, national interests [17].

Today art. 162 CAS of Ukraine empowers the court in deciding an administrative lawsuit to adopt a decision to declare illegal the decision of the subject of power or its individual provisions, actions or omissions and to cancel or invalidate the decision as a whole or its individual provisions [18].

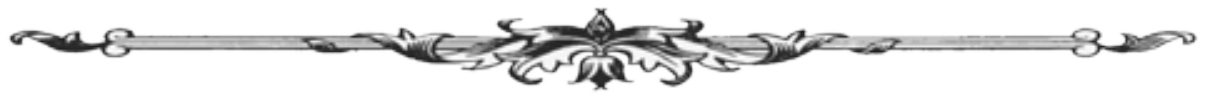


For the first time, the principle of the rule of law was enshrined in the legislation on administrative proceedings. The constitutional principle is realized, according to which a person and his rights are the highest social value, a citizen becomes not just a subject of the state, but a person endowed with his own rights, the realization of which seems quite real.

The course set by the Constitution of Ukraine for the development of a democratic, social, legal society requires new approaches to addressing the issues of improving the efficiency of the judiciary [6].

Proceedings by the administrative courts testifies to their effectiveness in the period of formation legal democratic state and economic reforms. Hope for protection from the illegal actions of the officials, since their inception, millions of citizens have to accept this protection, in spite of the resistance of officials of public authorities. However, in practice there is a change in the organization of work of public authorities, which are increasingly trying to provide the declared constitutional principles of the rights and freedoms of the individual, but the difficulties in the work of state bodies arise through legislation which is not fully adapted to modern realities, because it is taken long before the adoption of the Constitution of Ukraine. Disputes arise and on the basis of legislation adopted in compliance with the requirements of the Constitution of Ukraine, but not perfect.

There are a number of unresolved issues in the activities of administrative courts is the result of the economic situation in the country, the lack of norms that would regulate the administrative procedure in the Executive branch and, as you know, political bias [19].

Conclusion. The search for the optimal model of functioning of the judiciary and administration of justice has always been the main and quite challenging task of the state. In part to capitalize on other countries experience in the functioning of administrative courts in our country should introduce European standards in the judicial system reconciled and balanced. In most developed countries, such as, say, Germany, France or England other than the Ukraine's historical, social, political, legal and economic factors. And grafting on Ukrainian soil without taking into account national peculiarities of their model proceedings, there can be no assurance that we will receive the expected positive results.

\section{References:}

1. Авер'янов В.Б. Адміністративне право України: академічний курс : підручник: у 2 т. Т. 1. Загальна частина : Юрид. думка. 2004. 584 с.

2. Кобилянський К.М. Становлення адміністративних судів на землях сучасної України в період з 1917 по 1920 рік. Наше право. 2009. № 1. Ч. 1. С. 27-31.

3. Курко М.Н. Розвиток судової системи на території України - історичний аспект (XVIII-XIX століття). Часопис Київськ. ун-ту права. 2010. № 2. С. 35-38.

4. Бандурка А.М. Административный процесс : учебник. Литера ЛТД. 2002. 288 с.

5. Шаповал К.В. Історичний досвід становлення та розвитку судових установ, покликаних вирішувати земельні спори в Україні. Часопис Акад. адвокатури України. 2011. № 11. C. $97-107$.

6. Міщенко О.С. Правове регулювання здійснення адміністративного судочинства в умовах реформ та економічних перетворень : автореф... канд. юрид. наук : 12.00.07. Адміністративне право і процес; фінансове право;інформаційне право». Київ, 2011. 19 с.

7. Чаку Є.В. Становлення і розвиток адміністративного судочинства в Україні (від існування Київської Русі до здобуття незалежності). Форум права (Дніпропетровський державний університет внутрішніх справ). 2011. № 4. С. 801-806.

8. Конституція Союзу Радянських Соціалістичних Республік від 1977 p. URL : http://zakon.rada.gov.ua.

9. Димитров Ю. Адміністративна юстиція - атрибут демократичної правової держави. Право Украӥни. 1996. № 4. С. 7-14.

10. Кузьменко О.В. Адміністративна юстиція в Україні. Атіка. 2007. 156 с.

11. Коломоєць Т.О. Адміністративне судочинство. Істина. 2009. 344 с.

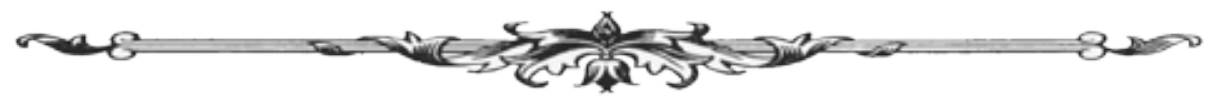


12.Авер'янов В.Б. Адміністративне право України : підручник. ТОВ «Вид-во «Юридична думка», 2007. 592 с.

13.Ківалов С.В. Адміністративне процесуальне (судове) право України. Юридична література. 2007. 312 с.

14. Указ Президента «Про утворення Вищого адміністративного суду України». URL : https:/www.president.gov.ua/documents/9412008-8090.

15.Конституція України: за станом на 1 травня 2020 p. URL : http//www.rada.gov.ua.

16.Педько Ю.С. Становлення адміністративної юстиції в Україні : монографія. Київ. 2003. $208 \mathrm{c}$.

17.Селіванов А.О. Адміністративне судочинство - новий інститут реалізації судової влади. Проблеми судово-правової реформи: URL : http://www.viaduk.net/clients/vs.nsf/0/1F84 B04D473311CEC32570BD00232346? OpenDocument\&CollapseView\&RestrictToCategory=1F8 4B04D473311CEC32570BD00232346\&Count=500\&.

18.Закон України «Кодекс адміністративного судочинства України». URL : https:// zakon.rada.gov.ua/laws/show/2747-15.

19.Копиленко О.П. Розвиток адміністративного судочинства (юстиції) в Україні. URL : http://westudents.com.ua/knigi/451-pravoznavstvo-kopilenko-op.html.

DZHEMLIKHANOV T. H., Security Specialist (Technotorg $L L C$ )

UDC 342.924

DOI https://doi.org/10.32842/2078-3736/2020.3.20

\section{APPLICATION OF ADMINISTRATIVE AND LEGAL REGULATIONS FOR CUSTOMS CLEARANCE ON CERTAIN TYPES OF SEA TRANSPORT}

The article is devoted to the study of the features of customs clearance in respect of certain types of sea transport. It has been established that the application of administrative and legal regulations in the implementation of customs clearance on sea transport, which belongs to a special type. The basic customs procedures for warships and naval vessels are determined. The specifics of such courts are characterized and reflected as representatives of state power. Highlighted the priority of customs measures in relation to such ships. Highlighted are the customs formalities in relation to coastal vessels and the goods by which they are transported. Ships engaged in coastal navigation are under customs control during the whole time of coasting. Customs formalities for a coastal vessel flying the State Flag of Ukraine end after it has completed coastal transportation and in the absence of goods and vehicles under customs control. It has been determined that shipment of a coastal vessel simultaneously with Ukrainian goods and foreign goods is permitted upon reliable identification, and if it is not possible to secure it, Ukrainian goods are placed on board the vessel separately from foreign goods. In addition, foreign goods are under customs control during the whole time of cabotage. Therefore, customs control is a multifaceted and diverse activity. For the implementation of customs control, customs control zones are created. At checkpoints across the state border of Ukraine, customs control zones are established by customs as agreed with the Border Troops. At points on the customs border of Ukraine, are the borders of special customs zones, customs independently determines the territory of customs control zones.

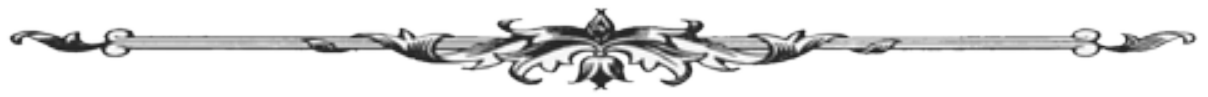

